EPiC Series in Engineering
Volume 3, 2018, Pages 1832-1840
HIC 2018. 13th International
Conference on Hydroinformatics

\title{
Modeling Surface Water-Groundwater Interaction in an Oxbow of the Drava Floodplain
}

\author{
Ali Salem ${ }^{1,2}$, József Dezső ${ }^{1}$, Dénes Lóczy ${ }^{1}$, Mustafa El-Rawy ${ }^{2}$, Marcin \\ Slowik $^{3}$ \\ ${ }^{1}$ Institute of Geography, Faculty of Sciences, University of Pécs, H-7624 Pécs, Hungary \\ ${ }^{2}$ Civil Engineering Department, Faculty of Engineering, Minia University, Minia 61111, Egypt \\ ${ }^{3}$ Faculty of Geographic and Geologic Sciences, Adam Mickiewicz University, 61-606, Poland \\ eng_ali_salem2010@mu.edu.eg
}

\begin{abstract}
Recently in Hungary, drought affects the Drava floodplain more severely than floods. The channelization of the Drava River changed the water budget of the CúnSzaporca oxbow lakes in the floodplain. The paper presents a 3-D groundwater model for this oxbow of the Drava floodplain to gain a better understanding of the water budget of the whole system under the normal situation and for different lake replenishment scenarios. The model is developed using the finite difference code MODFLOW-2005 and calibrated with a mean error of $-0.03 \mathrm{~m}$, and mean absolute error of $0.08 \mathrm{~m}$. Two scenarios for the replenishment of lake were analyzed. Water level is planned to be raised by $0.5 \mathrm{~m}$ and $1 \mathrm{~m}$, for the first and second scenario, respectively. As a consequence, an increase of seepage from the lake was found. Around $65 \%$ of the seepage recharges the groundwater system. Such a rise in groundwater table improves the sustainability of the aquifer and serves agricultural and environmental purposes. Additionally, they show the importance of the model for decision makers to select the right future management decisions.
\end{abstract}

\section{Introduction}

In the last centuries, $50 \%$ of European wetlands and more than $95 \%$ of riverine floodplains were converted to urban and agricultural lands [1]. The Water Framework Directive (WFD) provides a framework for an integrated management of rivers and wetlands [2]. River incision is a common reason for increasing drought hazard and the lowering of groundwater level in the adjacent floodplains [3]. In the historical periods several human activities lead to lower groundwater table and deteriorate the balance of natural systems [4]. Alluvial sediments indicate an extreme degree of heterogeneity in the hydraulic properties of sediment [5]. Exchange between alluvial aquifer system and surface water will be affected by the degree of the subsurface heterogeneity [6]. However, many 
studies address the interaction between the groundwater and surface water [7-9], the degree of subsurface heterogeneity for aquifer was rarely addressed.

Interactions between groundwater and surface water profoundly influence the provision of waterrelated ecosystem services. Floodplain areas provide places for aquatic ecosystems and shelters for bird population. Preserve and extend the mosaic pattern landscape, which is irrecoverable for biodiversity. This interaction influences water retention and the flood periods. The excess water caused reduced growth of crops, or total damage. The multi-layered sediments are crucial importance as geological background related to subsurface water dynamics. The knowledge of the role (in a hydrogeological means) of these layers is limited. Obviously, the randomly layered geological units cause anisotropy. Their position and extension modifies the velocity of subsurface flow. The optimal design of groundwater table is a complex task because of the conflicting demands of agriculture, forestry, flood control and nature conservation (for the Drava River floodplain see [3, 10].

The natural and/or artificial water budget is unbalanced; water supply is not efficient and sufficient for both agricultural activities and natural conservation. To solve the water scarcity problems, a largescale landscape rehabilitation project, the Old Drava Programme (ODP), was launched in 2013. The main objective of the ODP [11], implemented by Hungarian Government, is to provide holistic approach to water policy along the Drava river floodplain depending on the nature conservation and sustainable management of lake ecosystems and land.

In this project, one of the most important plans envisages water replenishment to oxbow lakes by raising their level from different sources. During the program, hydrological constructions (feeder canals, reservoirs, dams and sluices) were constructed to achieve the determined ideas. The length of the feeder canal is $3.1 \mathrm{~km}$ and canal has capacity of $0.4 \mathrm{~m} 3 \mathrm{~s}-1$. The Fekete-víz reservoir has to be filled to a minimum level of $93.1 \mathrm{~m}$ to ensure gravitational flow from the canal to the level of the oxbow lake by at least $0.5 \%$ slope. Unfortunately, the best plans often go wrong because they neglected the hydrogeological reality [12] and did not take into account the clogging of the feeding canal bottom. The first replenishment took place on March 2016 and not more than a $20 \mathrm{~cm}$ increase in lake level has been achieved.

The objective of this paper is to assess the interactions between groundwater and surface water at critical part of this system: between a protected oxbow (which is feeded by water according the ODP) and the main river (Drava). Further, to investigate the seepage from the lake, change in aquifer recharge, and the changes in groundwater levels under each scenario of oxbow lake(s) replenishment.

\section{Study Area}

The Drava River coincides with the border between Hungary and Croatia. The Drava oxbow is located in south-western of Hungary and covers an area about $2.57 \mathrm{~km} 2$ as depicted in (Figure. 1a, b). To assess the replenishment scenarios of oxbow lakes, a meander of the Drava River was selected as a case study. The meander was partially cut off from the new Drava channel during the first stage of channelization between 1842 and 1846 [13]. In a period of drought summer, the oxbow separate to five lakes. The study area is Lake Kisinc which is the largest oxbow lake of 20 ha area, with a maximum water depth of $2.4 \mathrm{~m}$ and an average water depth of $1.12 \mathrm{~m}$ [14]. This area is part of the Danube-Drava National Park and considered as a Ramsar Convention area. Satellite images (Google Earth) were used to identify the morphological features. The Ground Penetrating Radar (GPR) surveys were implemented to study the sediment layers in detail. Pumping test results [12] and borehole information were compared with GPR records (as depicted in Figure. 1c, d).

Surface water (lake and river) groundwater interactions were characterized by subdued ridge-andswale topography in the paleomeander systems. Albeit the area is topographically relatively uniform. Borehole sampling and GPR records showed extreme heterogeneity in the hydraulic properties of 
sediments. It was found that the fluvial landforms of area have four zones with different hydraulic conductivities. In situ saturated hydraulic conductivity for each borehole was measured using the fall head method [15] by using the following formula:

$k=\frac{L}{\left(t_{2}-t_{1}\right)} * \ln \left(\frac{h_{1}}{h_{2}}\right)$

where, $\mathrm{k}$ is saturated hydraulic conductivity, $\mathrm{L}$ is the height of the soil core, $\mathrm{t} 1$ and $\mathrm{t} 2$ are initial and final times of the experiment, respectively, $\mathrm{h} 1$ and $\mathrm{h} 2$ are the corresponding pressure head.The Geographic Information System ArcGIS 10.3 was used for preparing the input data to MODFLOW which used as a pre-processing step after MODFLOW to analyse and present results.

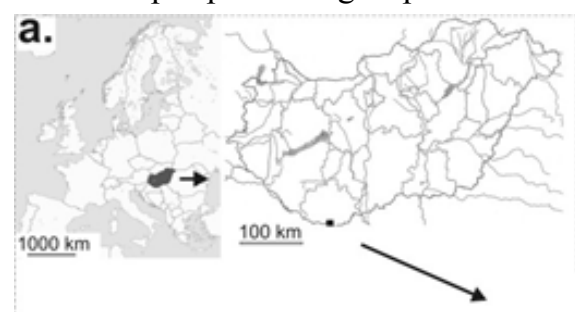

d.

b.

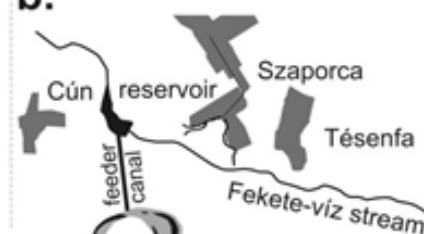

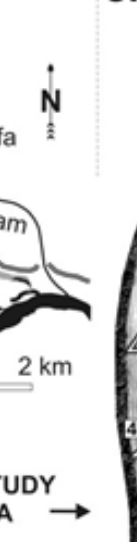

CASE STUDY
AREA $\rightarrow$

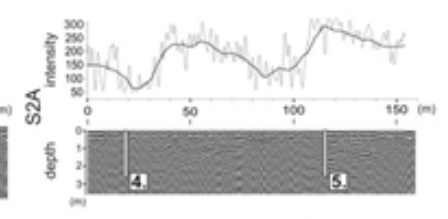

c.

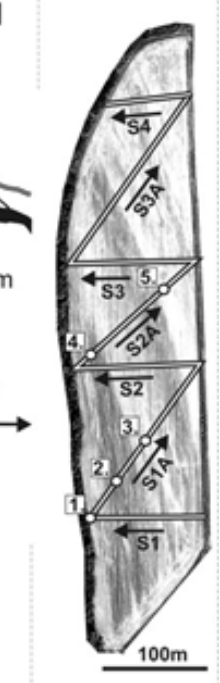

Figure 1: a) location of the research area; b) the Cún-Szaporca oxbow and surrounding area; c) direction and codes of GPR records, boreholes sites on in the case study area; d) Results of three important GPR records, with image gray scale intensities for Groundwater flow model setup

\section{Groundwater flow model setup}

The finite difference code MODFLOW-2005 [16], with ModelMuse [17] as a pre-processor graphical user interface, is applied to simulate groundwater flow. The model is discretized with a finite-difference grid that consists of 60 rows, 14 columns and 10 layers with cell size of $10 \mathrm{~m}$ by 10 $\mathrm{m}$ and with a total of 8400 cells, out of which 6540 are active cells. The top boundary of the model is represented by a 10-meter resolution Digital Elevation Model (DEM). The eastern and western boundaries are assigned with constant head values (interpolation between 89.68 and $90.69 \mathrm{~m}$ ) and (interpolation between 89.8 and $90.91 \mathrm{~m}$ ), respectively, based on initial groundwater level (see Figure 2). The modified version of [18] that based on water level fluctuation and rainfall depth $[19,20]$ was used of groundwater recharge of the study area $\mathrm{R}$ ( $\mathrm{mm} /$ year). By the following equation:

$\mathrm{R}=(\mathrm{P}-14)^{0.5}$

Where, $\mathrm{R}$ is the net recharge due to precipitation in inches, and $\mathrm{P}$ is the precipitation in inches

The groundwater recharge is found to be $2.5 \mathrm{E}-05 \mathrm{~m} \mathrm{~d}-1$. Estimation of evapotranspiration based on the water table fluctuations. The equation is given as [21]: 
$\mathrm{ET}=\mathrm{S}_{\mathrm{y}}(24 \mathrm{r} \pm \mathrm{s})$

where, ET actual daily evapotranspiration (L/day), Sy is the specific yield of soil, $r$ is hourly rate of groundwater inflow $(\mathrm{L} / \mathrm{h})$ that represent the mean hourly rate of groundwater level increase from midnight to $4.00 \mathrm{a} . \mathrm{m}, \mathrm{s}$ is the net rise of fall of water table during $24 \mathrm{~h}$ (L). The average daily evapotranspiration is estimated to $13 \mathrm{~mm}$.

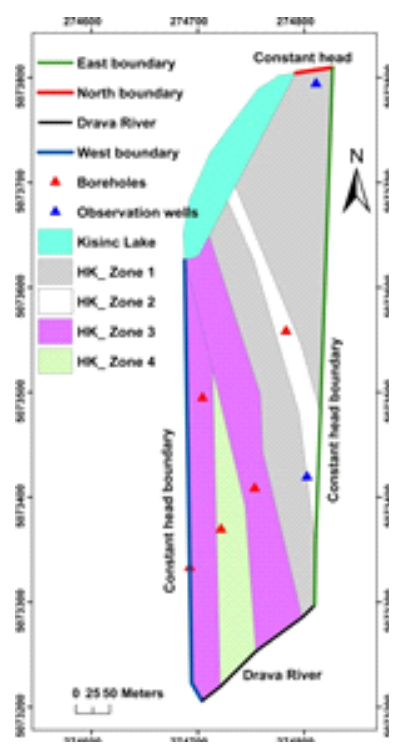

Figure 2: Hydraulic conductivity zonation, observation wells and the boundary conditions of the study area

\subsection{Model calibration}

3.1 The model is calibrated for steady-state using data from 3 boreholes and 2 observation wells (see Figure 2. The calibrated recharge is $1.35 \mathrm{E}-05 \mathrm{~m} \mathrm{~d}-1$, the conductance of riverbed is $150 \mathrm{~m} 2 \mathrm{~d}-1$ and the hydraulic conductivity of zone 1, zone 2, zone 3 and zone 4 are 6.75, 60, 6.75, $500 \mathrm{~m} \mathrm{~d}-1$, respectively. The results match with observed values with a correlation coefficient of $\mathrm{R} 2=0.94$ as depicted in (Figure 3) and the mean error is $0.03 \mathrm{~m}$, while absolute mean error is $0.08 \mathrm{~m}$. Moreover, simulated and observed heads are scattered around the mean values of observation heads which represent reliable model.

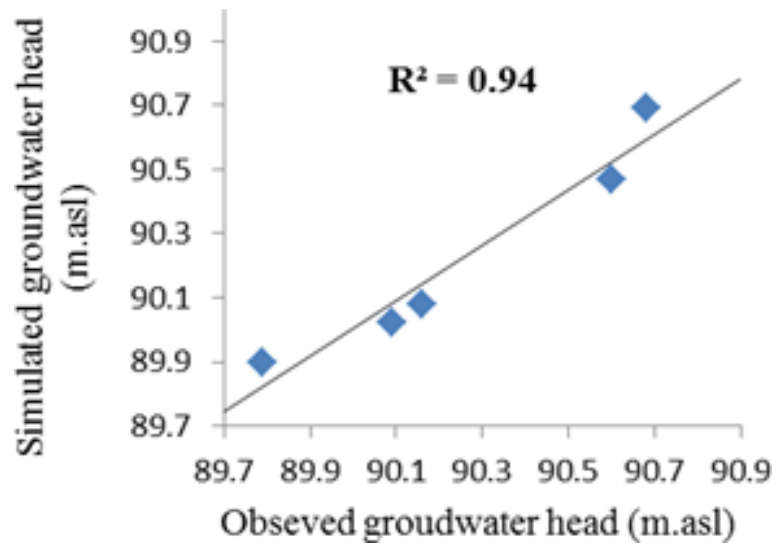

Figure 3: Scatter plot for simulated versus observed groundwater heads of steady states using five observation wells 


\subsection{Water Balance}

3.2 Table 1 showed the water balance of the calibrated model. The total amount of inflow from lake to aquifer is $891 \mathrm{~m} 3 \mathrm{~d}-1$ which represents $37 \%$ of the total inflow to aquifer and groundwater recharge from precipitation is $0.85 \mathrm{~m}^{3} \mathrm{~d}^{-1}$. The water budget of the system showed the importance of replenishment of oxbow lakes as a source to recharge aquifer and preserve the sustainability of ground water. The total discharge from aquifer to the river is $321.63 \mathrm{~m}^{3} \mathrm{~d}^{-1}$ while evapotranspiration accounted for $223.95 \mathrm{~m}^{3} \mathrm{~d}^{-1}$. An amount of $1167.50 \mathrm{~m}^{3} \mathrm{~d}^{-1}$ (or $48.87 \%$ ) recharges the aquifer from western boundary and 329.38 (only 13.79\%) from northern boundary. An amount of $1843.40 \mathrm{~m}^{3} \mathrm{~d}^{-1}$ (77.16\%) flows out the aquifer through the eastern boundary. This coincides with real situation that flows come from northern western direction to eastern direction.

Table 1: Water balance for the simulated steady state model

\begin{tabular}{|c|c|c|c|c|c|}
\hline & \multicolumn{2}{|c|}{ In } & \multicolumn{2}{|c|}{ Out } & \multirow{2}{*}{$\frac{\text { In-Out }}{\left(\mathrm{m}^{3} \mathrm{~d}^{-1}\right)}$} \\
\hline & $\left(\mathrm{m}^{3} \mathrm{~d}^{-1}\right)$ & $\%$ & $\left(\mathrm{~m}^{3} \mathrm{~d}^{-1}\right)$ & $\%$ & \\
\hline Eastern Boundary & 0.00 & 0.00 & 1843.4 & 77.16 & -1843.4 \\
\hline Northern Boundary & 329.38 & 13.79 & 0.00 & 0.00 & 329.38 \\
\hline Western Boundary & 1167.50 & 48.87 & 0.00 & 0.00 & 1167.5 \\
\hline Lake & 891.00 & 37.30 & 0.00 & 0.00 & 891.00 \\
\hline River & 0.00 & 0.00 & 321.63 & 13.46 & -321.63 \\
\hline Recharge & 0.85 & 0.04 & 0.00 & 0.00 & 0.85 \\
\hline Evapotranspiration & 0.00 & 0.00 & 223.95 & 9.38 & -223.95 \\
\hline Total & 2388.98 & 100 & 2388.98 & 100 & 0.00 \\
\hline
\end{tabular}

\subsection{Effect of model discretization}

To study the effect of the model discretization, various models were built. Summary of the simulated model discretization scenarios, water balance components and average groundwater level for every scenario are presented in Table 2 .

Table 2: Water balance components compared to the base case situation

\begin{tabular}{|c|c|c|c|c|c|c|c|}
\hline Case & $\begin{array}{l}\text { Inflow } \\
\text { through } \\
\text { constant } \\
\text { head } \\
\text { boundary }\end{array}$ & $\begin{array}{l}\text { outflow } \\
\text { through } \\
\text { constant } \\
\text { head } \\
\text { boundary }\end{array}$ & $\begin{array}{l}\text { Aquifer } \\
\text { recharge } \\
\text { (from } \\
\text { lake) }\end{array}$ & $\begin{array}{l}\text { Discharge } \\
\text { from } \\
\text { aquifer to } \\
\text { river }\end{array}$ & $\begin{array}{l}\text { Evapo - } \\
\text { trans- } \\
\text { piration }\end{array}$ & $\begin{array}{l}\text { Aquifer } \\
\text { recharge } \\
\text { from } \\
\text { precipitation }\end{array}$ & $\begin{array}{l}\text { Average } \\
\text { ground- } \\
\text { water } \\
\text { level }\end{array}$ \\
\hline & & & $\left(\mathrm{m}^{3} \mathrm{~d}^{-1}\right)$ & & & & m.asl \\
\hline $\begin{array}{l}\text { (1) Model } \\
\text { defined by } 6 \\
\text { zones and } 10 \\
\text { layers in } \\
\text { vertical } \\
\text { discretization }\end{array}$ & 1497.12 & 1843.39 & 891 & 321 & 223.95 & 0.85 & 90.26 \\
\hline $\begin{array}{l}\text { (2) Model } \\
\text { defined } 6 \\
\text { zones and one } \\
\text { layer for } \\
\text { vertical } \\
\text { discretization }\end{array}$ & 496.41 & 4195.83 & 4382.04 & 412.49 & 271.23 & 0.84 & 90.3 \\
\hline $\begin{array}{l}\text { (3) Model } \\
\text { characterized } \\
\text { by grid cell } 5 \mathrm{~m} \\
\text { by } 5 \mathrm{~m}\end{array}$ & 1910.10 & 2161.9 & 989.11 & 506.17 & 231.97 & 0.84 & 90.274 \\
\hline
\end{tabular}


Contour lines of the simulated groundwater levels of the model discretization scenarios with the base case are shown in Figure 4. The results clearly indicated that a major effect on the groundwater levels and water balance between the all scenarios. In case 2, the vertical discretization of the aquifer characterized by one layer with average vertical hydraulic conductivity, disregarding the sediment structure that reflected by the GPR investigation. Water leakage from the lake increases by $3491 \mathrm{~m}^{3} \mathrm{~d}^{-}$ ${ }^{1}$ with respect to the first case, resulting in the average groundwater level raise by $4 \mathrm{~cm}$ and increases in the amount of outflow through constant boundaries and ET increase. In case 3, with changing the cell size of the model to $5 \mathrm{~m}$ by $5 \mathrm{~m}$. The water balance component is quite similar to the base case, which recharge rate from the lakes to the aquifer increases by $98.11 \mathrm{~m}^{3} \mathrm{~d}^{-1}$ and discharge of aquifer to the river increases by $185.17 \mathrm{~m}^{3} \mathrm{~d}^{-1}$. The average groundwater level rises by $1.5 \mathrm{~cm}$ with respect to base case (Table 2). In case 4, the surface of the model defined by one zone with average horizontal hydraulic conductivity and one layer in vertical discretization, the simplification of sediments structure leads to increases in the seepage of the lake to groundwater system by $2846.23 \mathrm{~m}^{3} \mathrm{~d}^{-1}$ and discharge from aquifer to river increases by $2135.71 \mathrm{~m}^{3} \mathrm{~d}^{-1}$. The average water table rises by $8 \mathrm{~cm}$ regarding to first case.

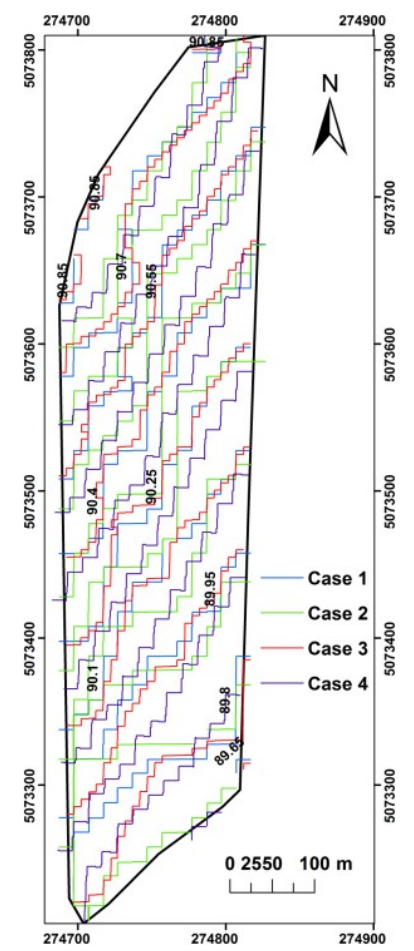

Figure 4: Contour lines of water table levels (m. asl) for model discretization scenarios compared with the base case.

\section{Replenishment Scenarios}

The baseline scenario represents the existing situation of the lake without replenishment, with water level at $90.5 \mathrm{~m}$ above sea level. This case is applied to calibrate the steady state model and to compare the results with replenishment scenarios. Two hydrological scenarios of lake - replenishment by setting two different lake water levels (91 and $91.5 \mathrm{~m}$. asl) are applied to analyze the responses of the groundwater system. 


\subsection{Results and discussions}

In the basic scenario (i.e., in the absence of the lake replenishment) in which lake stage is at 90.5 m. asl., the results show that leakage (outflow from the lake) is $895 \mathrm{~m}^{3} \mathrm{~d}^{-1}$ and the outflow from evapotranspiration is $18 \mathrm{~m}^{3} \mathrm{~d}^{-1}$. Discharge from aquifer to river is $721 . \mathrm{m}^{3} \mathrm{~d}^{-1}$, from which the recharge from lake to aquifer is $174.95 \mathrm{~m}^{3} \mathrm{~d}^{-1}$ and the average groundwater level is $89.68 \mathrm{~m}$. asl. Figure 5a shows the distribution groundwater head for the basic case. The results of the simulated scenarios are summarized in Table 3. In the first replenishment scenario, with increasing the lake water by $0.5 \mathrm{~m}\left(91 \mathrm{~m}\right.$. asl). The seepage from the lake is $1,298.8 \mathrm{~m}^{3} \mathrm{~d}^{-1}$ and outflows through evapotranspiration rise by $161.20 \mathrm{~m}^{3} \mathrm{~d}^{-1}$ in respect to the baseline situation. Average groundwater level rises by $0.28 \mathrm{~m}$. In the second scenario, at the maximum lake stage of $91.5 \mathrm{~m}$. asl, recharge rate from the lake to the aquifer increases by $745.59 \mathrm{~m}^{3} \mathrm{~d}^{-1}$ compared to the baseline case. Consequently, average water table rises by $0.77 \mathrm{~m}$ and the amount of evapotranspiration outflow increases.

Table 3: Water budget components and changes in groundwater level compared to the baseline situation

\begin{tabular}{lccccc}
\hline Scenario & $\begin{array}{c}\text { Average } \\
\text { lake level }\end{array}$ & $\begin{array}{c}\text { Aquifer } \\
\text { recharge } \\
\text { from lake }\end{array}$ & $\begin{array}{c}\text { Discharge } \\
\text { from aquifer } \\
\text { to river }\end{array}$ & $\begin{array}{c}\text { Evapo- } \\
\text { transpiration }\end{array}$ & $\begin{array}{c}\text { Average } \\
\text { change of } \\
\text { groundwater } \\
\text { level }\end{array}$ \\
\cline { 2 - 6 } & $(\mathrm{m} . \mathrm{asl})$ & & $\left(\mathrm{m}^{3} \mathrm{~d}^{-1}\right)$ & & $(\mathrm{m})$ \\
\hline $\begin{array}{l}\text { Baseline case } \\
\text { 1st }\end{array}$ & 90.5 & 895.96 & 721.02 & 18 & 0 \\
$\begin{array}{l}\text { replenishment } \\
\text { 2nd } \\
\text { replenishment }\end{array}$ & 91 & 1298.3 & 446.71 & 180.8 & 0.28 \\
\hline
\end{tabular}

a)

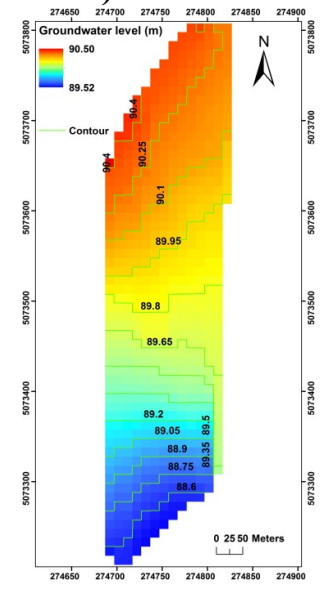

b)

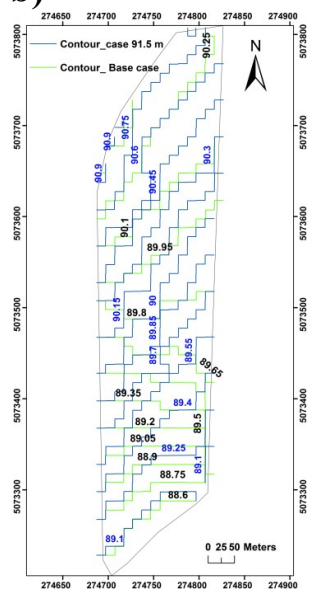

Figure 5: a) Simulated groundwater head contour map for basic scenario; b) Head contours for maximum replenishment lake stage $91.5 \mathrm{~m}$.asl with head contours of basic scenario

Simulated groundwater head contours for the second scenario with the head contours of the basic scenario are presented in (Figure 5b). All results point out the planned replenishment scenarios of the lake will raise the groundwater level and augment, on the average, the groundwater system by over 65 $\%$ of the leakage from the lake. 


\section{Conclusion}

The effects of different water management scenarios were studied for the lake replenishment to the Cún-Szaporca oxbow. A 3-D groundwater model was developed to gain a better understanding of groundwater-surface water interactions in the oxbow by using MODFLOW 2005. The model was applied to assess the water budget through calculating the changes in streams and groundwater system under a set of different lake water levels. The increase in water level to 91 and $91.5 \mathrm{~m}$. asl would result in raising the average groundwater level by 0.28 and $0.77 \mathrm{~m}$, respectively, compared to the baseline case $(90.5 \mathrm{~m})$. The simulated scenarios showed that the rate of recharge from the lake to aquifer increased by 677.17 and $745.59 \mathrm{~m}^{3} \mathrm{~d}^{-1}$, respectively. Water budget for the simulated scenarios will maintain the ecosystem and agriculture water in equilibrium. These outcomes will help the planners and the stakeholders in planning and management of water resources in the oxbow area.

\section{Acknowledgements}

The present scientific contribution is dedicated to the 650th anniversary of the foundation of the University of Pécs, Hungary. The authors are grateful to the South-Transdanubian Water Management Directorate for providing access to the necessary data.

\section{References}

[1] B. Gumiero, J. Mant, T. Hein, J. Elso, B. Boz, Linking the restoration of rivers and riparian zones/wetlands in Europe, Sharing knowledge through case studies, Ecological Engineering, 2013, 56, pp. 36-50.

[2] EC, Directive 2000/60/EEC, Establishing a framework for community action in the field of water policy, Official Journal of the European Communities, Luxemburg. 2000, L327, PP. 171.

[3] D. Lóczy, J. Dezső, Sz. Czigány, P. Gyenizse, E. Pirkhoffer, A. Halász, Rehabilitation potential of the Drava River floodplain in Hungary, Water resources and wetlands, Conference proceedings, Tulcea, Romania, 11-13 September 2014, Transversal Publishing House, Targoviste, 2014, pp. 21-29.

[4] RJ. Hu, ZL. Fan, and YJ. Wang, Groundwater resources and their characteristics in arid lands of Northwestern China, J Nat Resour, 2002, vol. 17, no. 3, pp. 321-326.

[5] A. D.Miall, The geology of fluvial deposits: sedimentary facies, basin analysis, and petroleum geology. Springer, Berlin ; New York,1996.

[6] J. Dezső, A. Salem, D. Lóczy, S. Marcin, P. Dávid, , Randomly layered fluvial sediments influenced groundwater-surface water interaction, 17th International Multidisciplinary Scientific GeoConference SGEM 2017, Conference proceeding volume 17, water resourse,forest, Marin and ocean ecosystemes Issue 33, Vienna, Austeria, 27-30 November,2017.

[7] M.Sophocleous, Interactions between groundwater and surface water: the state of the science. Hydrogeology Journal 10, no. 1:52-67, 2002.

[8] S.Rudnick, J.Lewandowski , G.Nützmann, Investigating groundwater-lake interactions by hydraulic heads and a water balance, Groundwater 53:227-237, 2015. doi:10.1111/gwat.12208.

[9] M. El-Rawy, Z.Vitaly,A. Marwan, A. Ali , K.Anvar , A. Osman, Conjunctive use of groundwater and surface water resources with aquifer recharge by treated wastewater: 
evaluation of management scenarios in the Zarqa River Basin, Jordan, Environ Earth Sci, 2016, 75:1146 DOI 10.1007/s12665-016-5946-1

[10] Pécsi HIDROTERV Bt., Ös-Dráva Program Aktualizált Területi Vízgazdálkodási Tanulmányterv (Old Drava Programme, Actualized Plan for Regional Water Management), Pécsi HIDROTERV Bt., Pécs, 2015, 180 p. (in Hungarian) http://vpf.vizugy.hu/reg/ddvizig/doc/Osdrava\%20tanulmany.pdf

[11] AQUAPROFIT, Az Ormánság komplex rehabilitációja és térségfejlesztése, Ös-Dráva Program (Complex rehabilitation and regional development in Ormánság. Old Drava Programme), AQUAPROFIT, Budapest, 2005, 516 p. (in Hungarian)

[12] J. Dezső, A. Halász, Sz. Czigány, G.Tóth, and D. Lóczy, Estimating seepage loss during water replenishment to a floodplain oxbow, A Case study from drava plain, Geogr. Fis. Dinam. Quat. 40,2017, 61-75 DOI 10.4461/ GFDQ 2017.40

[13] J. Dezső, A. Halász, G. Tóth, J. Miřijovský, D. Lóczy, potential changes in the landscape due to ox-bow revitalization (case study from drava-basin, Hungary, role of fieldwork in geomorphology, Annual conference of the Czech Association of Geomorphologists, 10-13 March 2015, pp. 22-23

[14] DDKÖVÍZIG, Revitalization of the Cún-Szaporca oxbow system. Final Master Plan, SouthTransdanubian Environment and Water Directorate, Pécs, 2012, 100 pp.

[15] W.reynolds \& D.e. elrick, Pressure infltrometer: Part 4. Physical methods. In: Dane J.H. \& ToPP G.C. (Eds.) Methods of Soil Analysis. Madison, WI. Soil Science Society of America, 826-836, 2002.

[16] A.W. Harbaugh, MODFLOW-2005, the U.S. Geological Survey Modular Ground-water Model - the Ground-water Flow Process. US Geological Survey Reston, Virginia, 2005.

[17] R.B. Winston, ModelMuse - A graphical user interface for MODFLOW - 2005 and PHAST. U.S. Geological Survey Techniques and Methods, 2009. , 6-A29, 52pp.

[18] R.S. Chaturvedi, A note on the investigation of ground water resources in western districts of Uttar Pradesh. In Annual Report; U.P. Irrigation Research Institute: Bahadrabad, India, 1973, pp. 86-122.

[19] R. Allen, L.A.Pereira, D.Raes, M.Smith, Crop evapotranspiration. In FAO Irrigation and Drainage Paper No. 56; FAO: Rome, Italy, 1998.

[20] B.D.R.Misstear, L.Brown, D.Daly, A methodology for making initial estimates of groundwater recharge from groundwater vulnerability mapping. Hydrogeol. J. 2009, 17, pp. 275-285.

[21] W.N. White, Method of estimating groundwater supplies based on discharge by plants and evaporation from soil - results of investigation in Escalante Valley, Utah - US Geological Survey. Water Supply Paper 659-A, 1-105, 1932. 